\title{
Design, Manufacture and Performance Evaluation of an Effective Dual Operated Groundnut Decorticator with Blower
}

\author{
Enoch Asuako Larson ${ }^{1,}$, Philip Yamba ${ }^{1}$, Anthony Akayeti ${ }^{1}$, Samuel Adu-Gyamfi ${ }^{2}$ \\ ${ }^{1}$ Department of Mechanical Engineering, Tamale Technical University, Tamale, Ghana \\ ${ }^{2}$ Department of Mechanical Engineering, Sunyani Technical University, Sunyani, Ghana
}

Email address:

easuako@rocketmail.com (E. A. Larson)

*Corresponding author

\section{To cite this article:}

Enoch Asuako Larson, Philip Yamba, Anthony Akayeti, Samuel Adu-Gyamfi. Design, Manufacture and Performance Evaluation of an Effective Dual Operated Groundnut Decorticator with Blower. International Journal of Mechanical Engineering and Applications. Vol. 5, No. 2, 2017, pp. 107-111. doi: 10.11648/j.ijmea.20170502.15

Received: February 27, 2017; Accepted: March 9, 2017; Published: March 28, 2017

\begin{abstract}
A manual (hand operated or bicycle paddle) groundnut decorticating machine attached with a blower is designed, manufactured and its performance assessed. The main components of the machine were the frame, hopper, neck feed control gate, shelling drum, shaft running on bearings, a pneumatic type mechanism, concave sieve and a blower. The rest are pulley and sprocket, discharge outlet and belt drive. The assembled angle iron parts were welded together whiles the sheet metal parts were riveted to hold in position. Testing of the decorticating machine was assessed at three different moisture contents of groundnut $(0,5.1$ and 9.3\%) and three different levels of machine shaft speed $(10,20$ and $30 \mathrm{rpm})$ all at an average feed rate of $25 \mathrm{~kg} / \mathrm{hr}$. The results revealed that the decorticating machine's optimum performance was at $20 \mathrm{rpm}$ machine shaft speed with groundnut moisture content of $0 \%$ (purely dry), machine cracking efficiency and percentage groundnut fully cracked was $71.2 \%$ and $85.3 \%$ respectively. There was reduction in machine performance at machine speeds of $10 \mathrm{rpm}$ and $30 \mathrm{rpm}$ with $45.1 \%$, and $49.7 \%$ machine cracking efficiency respectively for the same feed gate rate openings. This was because at a speed of $10 \mathrm{rpm}$, the nuts were partially cracked (41.6\%) and that of $30 \mathrm{rpm}$ and cracked $(39.3 \%)$, the quantum of groundnut losses through the blower increased considerably leading to a reduction in the quantity of groundnut collected.
\end{abstract}

Keywords: Groundnut, Manual, Blower, Cracking Efficiency, Moisture Content

\section{Introduction}

Groundnut (Arachis Hypogaea L.) is also known as peanut, earthnut, monkey nut and goobers [1], and in its various forms is one of the most commonest diets and a major cash crop in the Northern part of Ghana and an important sources of oil (kernel contains 42-52\% oil), vegetable protein (kernel contains $20-50 \%$ ), fat (40-50\%), carbohydrate $(10-20 \%)$ for both domestic and industrial need [2]. Peanut is grown on nearly 23.95 million ha worldwide with a total production of 36.45 million tons and an average yield of $1520 \mathrm{~kg} / \mathrm{ha}$ in 2009. Between 2000 and 2009, the annual global production of groundnut increased marginally by $0.4 \%$, the area by $0.3 \%$ and yield by $0.1 \%$ [3].

The least world's producer of groundnut is Ghana. In
2012, groundnut farmers produced $73,871.70$ tons of groundnut from 84,910 ha with an average yield of 0.87 tons per ha, though 2 tons per ha was achievable under severe rain fed condition [4] as compared to China one of the world's largest groundnut producers, with $40 \%$ of the world's production, followed by India with $23 \%$, a group of SubSaharan African (SSA) countries with $8 \%$ and the United States (US) with 5.6\% [5].

In Ghana, groundnut is grown throughout the country, but it is mostly cultivated in the Northern regions where about $92 \%$ of the national production emanates [6]. The national per capita groundnut consumption was estimated at $0.61 \mathrm{~kg} /$ week (0.03172 metric tons $/$ year $)$ and $80 \%$ of Ghanaians consume groundnuts or its produce at least once a week [7]. 
Traditionally, groundnut cracking in Ghana is mostly done by either placing the pods in the hand and snapping it with your fingers manually, causing the shell to split leaving the nut out, or gently pounding the groundnuts with a mortar and a pestle, or rubbing with a wooden board on cemented floors, tables etc. This is normally done by small scale farmer groups which is labour intensive, time consuming and associated with pain and injury. In the case of placing the nuts in the fingers, it is usually sustained for long periods till the cracking is over.

The design and manufacture of groundnut decorticating machine in Ghana has not advanced over time with any new technological inventions and innovations thus still making the conventional method of processing the groundnut predominate. There are other forms of groundnut decorticating machine. These are the universal nut decorticator, the hand operated cracker, the manual way of groundnut cracking, the motorized groundnut decorticator and the foot operated cracker.

Therefore, this research is aimed at designing and manufacturing of a groundnut decorticating machine attached with a blower is focused on shelling of groundnut with optimal energy, high efficiency and ease of nut separation due to the blower for the rural dueler.

\section{Materials and Methods}

\subsection{Description of Machine and Operation}

The machine parts consist of the hopper, cracking chamber, link mechanism, shaft, pulley, bearing and bearing housing, the main frame, the blower, the chain and sprocket. The hopper is designed in a trapezoidal shape made from a galvanized sheet plate of $1 \mathrm{~mm}$ thickness. The hopper upper dimension is $500 \mathrm{~mm}^{2}$ and that of the lower dimension is 250 $\mathrm{mm}^{2}$ with a slant height of $400 \mathrm{~mm}$ at $45^{\circ}$. The hopper is the feeding chamber through which the groundnuts are fed into the machine cracking chamber. The cracking chamber consist of a grinder (tyre) and a sieve sheet. The driving mechanism consist of a chain and sprocket and a V-belt pulley which can be operated either by sitting and paddling and or hand operated respectively (See Figure 1 and Figure 2).

The cost of the machine is affordable due to availability of raw materials. When in operation, the groundnuts are separated by the blower providing separate outlets for the cracked groundnut and the chaff. Table 1 is the name of part and the type of materials used.

The groundnut samples were prepared by placing in a localized boiler at the various moisture contents and calculated by the following formula [8].

$$
\mathrm{Q}=\mathrm{W}_{i}\left(\mathrm{M}_{f}-\mathrm{M}_{t}\right)\left(100-\mathrm{M}_{f}\right)
$$

Where, $\mathrm{W}_{i}, \mathrm{M}_{t}$ and $\mathrm{M}_{f}$ are the initial mass $(\mathrm{g})$, initial moisture content (\% d.b.) and final moisture content of the samples (\% d.b.) respectively.

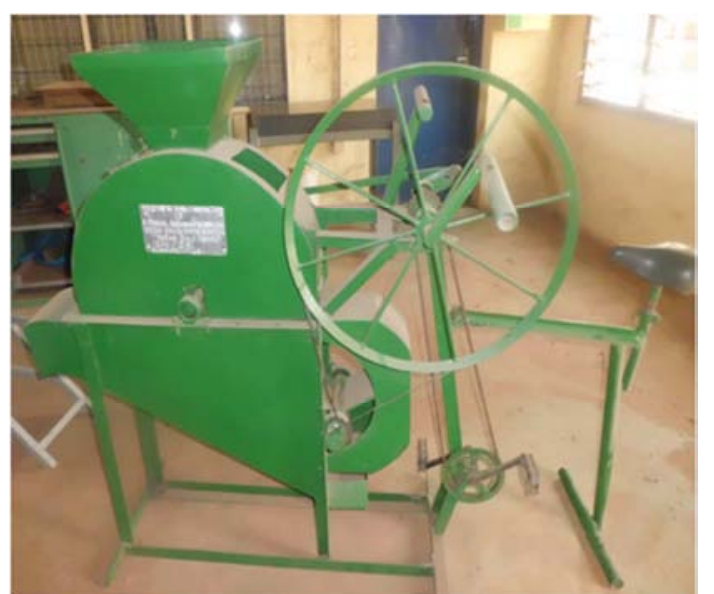

Figure 1. Pictorial view of the groundnut decorticating machine.

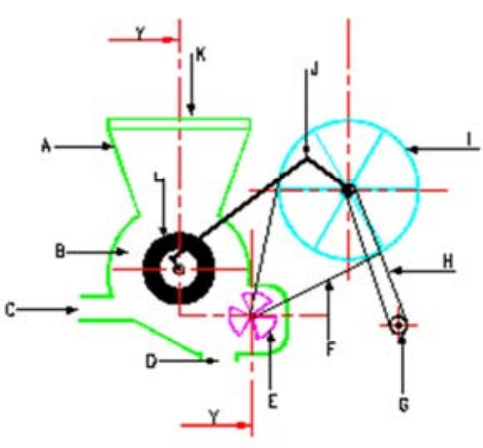

EEVATION

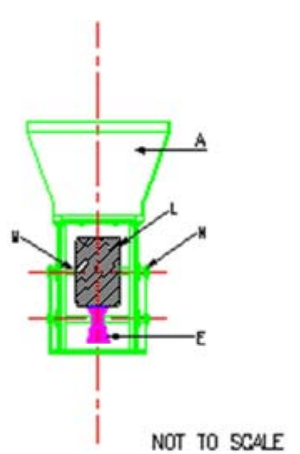

SECTION $Y-\gamma$
Figure 2. Elevation and section y-y of machine.

Nomenclature: A-Hopper, B-Cracking chamber, C-Groundnut chaff outlet, D-Groundnut outlet, E-Blower, F-Belt drive, G-Sprocket, H-Chain drive, IPulley, J-Link mechanism, K-Feed, L-Grinder (tyre), M-Shaft and NBearing and housing.

Table 1. Materials used for the groundnut decorticating machine.

\begin{tabular}{lll}
\hline S/N & Part Name & Material \\
\hline 1 & Hopper & Galvanized sheet \\
2 & Body of machine & Galvanized sheet \\
3 & Blower & Mild steel \\
4 & Pulley & Mild steel \\
5 & Handle & Mild steel \\
6 & Shaft & Mild steel \\
7 & Stand & Angle iron (Mild steel) \\
8 & Chain/sprocket & Mild steel \\
\hline
\end{tabular}

\subsection{Design Considerations}

The following are design factors that were taken into consideration. Fabrication of the machine components were considered for having the need for periodic servicing, the use of temporary joints or fasteners to facilitate dismantling or disassembling during cleaning, servicing and or transportation was very necessary.

i. Overall cost of the machine was considered based on the Life Cycle Cost (LCC) of the machine throughout the design stage, material selection stage and the fabrication stage which at the long run would be affordable to users of the machine, especially local farmers.

ii. Grain factors such as shape, size and moisture content 
levels were considered in the design of the decorticating machine for easy separation of the nut from the shell by the blower.

iii. The machine was constructed with the use of availability of local materials to ensure the need of possible replacement of damage parts that are not expensive but available and easily affordable in the local market.

iv. Operating accessories of the machine were positioned on the basis of easy handling and safety of the user and others within the operating zone.

v. Machine factors such as strength, robustness, stability, rigidity, vibration and noise were appropriately considered in the material selection for the various machine and rotating parts.

vi. The machine blower was designed not to use energy from an external source such as from national grid or solar source.

\subsection{Design Analysis}

The main designs of the machine were the hopper, pulley, belt and chain drive, blower and the shaft.

\subsubsection{The Hopper}

The groundnut decorticator is estimated to have a maximum capacity of $350 \mathrm{~kg} / \mathrm{hr}$. Hence, the hopper is designed in a pyramidal frustum to ensure easy flow of the groundnuts without hindrance or interference. The top opening of the hopper is $360 \mathrm{~mm} \times 360 \mathrm{~mm}$ whiles the base opening is $100 \mathrm{~mm} \times 100 \mathrm{~mm}$ with a side length of $40 \mathrm{~mm}$ inclined at an angle of $45^{\circ}$. The angle was selected to allow free flow of the groundnuts into the cracking chamber.

\subsubsection{Pulley}

\section{Power Requirement}

The machine is designed to be operated manually either by paddle link with a chain system or by hand with a pulley system. Factors such as operator height, weight and age were critically considered in the design and required a minimum pressure for optimum efficiency. The manual operation for the machine was selected as a result of the rampant power outages experienced in Ghana and will be helpful in the rural areas where lots of groundnuts farming activities are done.

\subsubsection{Drive mechanism}

\section{i. Shaft Design}

The shaft considered for optimum performance is to be tough, wear resistance and high strength. The need for a solid circular shaft was necessitated for analysis for its combined bending and torsional stresses. The calculation for the shaft diameter was determined using the Association of Mechanical Engineers (ASME) code equation for solid shaft having little or no axial loadings.

$$
d^{3}=\frac{16}{\pi \sigma_{s}} \sqrt{\left(k_{t} M_{t}\right)^{2}+\left(k_{b} M_{b}\right)^{2}}
$$

Where $\sigma_{\mathrm{s}}=$ Ultimate stress of mild steel with keyway, $\left(\mathrm{N} / \mathrm{m}^{2}\right), \mathrm{d}_{\mathrm{o}}=$ shaft outside diameter, $(\mathrm{m}), \mathrm{d}_{\mathrm{i}}=$ shaft inside diameter, $(\mathrm{m}), \mathrm{k}_{\mathrm{b}}=$ combined shock and fatigue factor applied to bending moment, $\mathrm{k}_{\mathrm{t}}=$ combined shock and fatigue factor applied to torsional moment (for rotating shaft with suddenly applied load), $\mathrm{M}_{\mathrm{t}}=$ Maximum bending moment.

\section{ii. Determination of Shaft Diameter}

The following formula was used to determine the shaft diameter.

$$
d^{3}=16 / \pi \mathrm{Ss}\left[\left(\mathrm{K}_{\mathrm{b}} * \mathrm{M}_{\mathrm{b}}\right)^{2}+\left(\mathrm{K}_{\mathrm{t}} * \mathrm{M}_{\mathrm{t}}\right)^{2}\right]^{1 / 2}
$$

Where, $\mathrm{d}=$ diameter of shaft

$\mathrm{Ss}=$ allowable stress $\left(55 \mathrm{MN} / \mathrm{m}^{2}\right.$ for shaft without keyway and $40 \mathrm{MN} / \mathrm{m}^{2}$ for shaft with keyway)

$\mathrm{K}_{\mathrm{b}}=$ factor for gradually applied load $=1.5$

$\mathrm{K}_{\mathrm{t}}=$ factor for suddenly applied load $=1.5$ [9].

\section{iii. Determination of Belt Tensions}

$$
\frac{T_{1}}{T_{2}}=\left[\ell^{\mu_{\theta}}\right]
$$

But $\mathrm{P}=\left[\left(\mathrm{T}_{1}-\mathrm{T}_{2}\right) \mathrm{V}\right]$

$$
\begin{gathered}
\mu=0.21[10] \\
\mathrm{T}_{\mathrm{c}}=\left[\frac{1}{3} \mathrm{~T}_{1}\right] \\
\left(T_{1}-T_{c}\right) /\left(T_{c}-T_{c}\right)=\left[\left(\ell^{\mu i \operatorname{Sin} \theta}\right)\right] \\
\mathrm{T}_{1}=350.61 \mathrm{~N} \text { and } \mathrm{T}_{2}=205.72 \mathrm{~N}
\end{gathered}
$$

\subsection{Determination of Included Angle ( $\beta$ ) and Angle of} Wraps $(\alpha)$ in $V$-belt Arrangement

Centre distance $\left.\mathrm{C}=\mathrm{A}+\left[A^{2}+B^{2}\right)^{1 / 2}\right]$ Where $\mathrm{A}=\left[L P / 4+\pi / 8 \quad\left(\begin{array}{lll}D_{1} & - & D_{2}\end{array}\right]\right.$

$$
\begin{gathered}
\mathrm{B}=\left[\begin{array}{ll}
\left.\frac{\left(D_{1}-D_{2}\right.}{8}\right)^{2} \\
8
\end{array}\right] \\
\cos \theta / 2=\left[\begin{array}{ll}
\left(D_{1}-D_{2}\right) / C
\end{array}\right] \\
\theta=215.17^{\circ} \\
\sin \beta=\left[\left(\begin{array}{ll}
\left(D_{1}-D_{2}\right) / C
\end{array}\right]\right. \\
\beta=3.71^{\circ}
\end{gathered}
$$

Therefore, the angle of wrap are calculated from the following;

$$
\begin{aligned}
& \alpha_{1}=[180-2 \beta] \\
& \alpha_{2}=[180+2 \beta]
\end{aligned}
$$

\subsection{Determination of Moisture Content (MC)}

The sampled groundnuts were weighed separately in an analogue weighing balance and placed in a localized boiler for $2 \frac{1}{2} \mathrm{hrs}\left(100^{\circ} \mathrm{C}\right)$ at $5.1 \%$ (d.b.), $4 \mathrm{hrs}\left(120^{\circ} \mathrm{C}\right)$ for $9.3 \%$ (d.b. $)$ and $0 \%$ (d.b.) at ambient temperature using a thermometer. The moisture content (d.b.) was determined by the expression: 


$$
\% \mathrm{MC} \text { (d.b.) }=\left[\frac{W 1-W 2}{W 2}\right]
$$

Where d.b. is the dryness fraction, $W_{l}$ is the initial weight of the groundnut $(\mathrm{g})$ and $W_{2}$ is the final weight of the groundnut $(\mathrm{g})$.

\subsection{Machine Performance Test Process}

A Quantifiable amount of groundnut was purchased from a small scale groundnut mill in the Choggu-Manayili a suburb of Tamale-Ghana for the performance test. Before decorticating, the groundnuts were dried at different moisture content levels for easy decorticating of the nuts from the shell. In all, a total of $350 \mathrm{~kg}$ of the groundnuts were fed into the machine for the test run at a feed-rate of $25 \mathrm{~kg} / \mathrm{hr}$. The moisture content levels were also varied for the experimentation $(0,5.8$, and 9.3\%) and machine varying speed of $(10,20$ and $30 \mathrm{rpm})$. After each operation, the quantity of damaged and undamaged or cracked and un-cracked groundnut were sieved and weighed. Each of the tests was carried out at three different times, their averages calculated for the determination of the throughput, cracking efficiency, percentage groundnut breakage under the various conditions.

The following formulas were adopted in finding the evaluated parameters.

Efficiency, $\mathrm{E}_{\mathrm{c}}$

$$
E_{c}=\left(G_{t}-G_{n}\right) / G_{t}
$$

$\mathrm{G}_{\mathrm{t}}=$ weight of fully cracked groundnut $(\mathrm{kg})$ (kg)

$\mathrm{G}_{\mathrm{n}}=$ weight of partially cracked/un-cracked groundnut

Percentage groundnut breakage, $\mathrm{P}_{\mathrm{gb}}$

$$
\mathrm{P}_{\mathrm{gb}}=\mathrm{C}_{\mathrm{d}} /\left(\mathrm{C}_{\mathrm{d}}+\mathrm{C}_{\mathrm{u}}\right) \times 100
$$

$\mathrm{C}_{\mathrm{d}}=$ weight of cracked and damaged groundnut $(\mathrm{kg})$

$\mathrm{C}_{\mathrm{u}}=$ weight of cracked and undamaged groundnut $(\mathrm{kg})$

Feet rate, $\mathrm{Fr}$

$$
\mathrm{F}_{\mathrm{r}}=\mathrm{G}_{\mathrm{t}} / \mathrm{T}_{\mathrm{t}}
$$

$\mathrm{G}_{\mathrm{t}}=$ weight of the groundnut fed into the hopper $(\mathrm{kg})$ and $\mathrm{T}_{\mathrm{t}}=$ time taken to empty the whole groundnut into the cracking chamber (hr.).

Throughput capacity, $\mathrm{T}_{\mathrm{c}}$

$$
\mathrm{T}_{\mathrm{c}}=\mathrm{G}_{\mathrm{T}} / \mathrm{T}_{\mathrm{T}}
$$

Where, $\mathrm{G}_{\mathrm{T}}=$ the total weight of the groundnuts fed into the machine $(\mathrm{kg})$ and $\mathrm{T}_{\mathrm{T}}=$ the total time take by the cracked mixture to leave the discharge outlet (hr).

\subsection{Maintenance}

Periodic maintenance of the machine is required every quarterly. Rotating parts should be protected and frequently greased.

\section{Results and Discussion}

The performance evaluation results showed that the optimum performance is influenced by the tyre pressure in the hopper chamber, the groundnut moisture content and the machine spindle speed. The average feed rate was at $25 \mathrm{~kg} / \mathrm{hr}$, the shaft cracking increased as the cracking efficiency increased. The speeds of $10 \mathrm{rpm}, 20 \mathrm{rpm}$ and $30 \mathrm{rpm}$ generated a machine cracking efficiency of 45.1, 71.2 and $49.7 \%$ respectively with the moisture contents of $9.3,0$ and $5.1 \%$ (d.b.) respectively.

At $0 \%$ (d.b.) moisture content, showed the best cracking evaluation performance of $71.2 \%$ at $20 \mathrm{rpm}$ shaft speed, groundnut breakage of $14.7 \%$ and groundnuts cracked of $85.3 \%$. This is due to the groundnut dryness thus providing the optimum shaft speed.

Other evaluation tests revealed that the machine cracking efficiency was increased with a decrease in moisture content at the same shaft speed. At $5.1 \%$ (d.b.) moisture content, the machine efficiency was $29.3,66.9$ and $31.6 \%$ which could be due to inherent factors but experienced a decrease in groundnut cracked rate and high breakage as in Fig. 3 (b). At $9.3 \%$ (d.b.) moisture content, the cracking efficiency was $35.2,66.3$ and $27.0 \%$ with $69.5 \%$ high groundnut breakage at $10 \mathrm{rpm}$ shaft speed and as low as $16.6 \%$ groundnut breakage at $20 \mathrm{rpm}$ shaft speed as in Fig. 3 (c). This was as a result of higher moisture contents which required more energy to crack under same conditions and some caused slippage.

Consequently, an increase is the shaft spindle speed resulted in the increase of groundnut damage. Furthermore, evaluation of the test conducted revealed that the throughput capacity increases with the increase in machine shaft speed at the same condition. Hence, the overall performance of the groundnut decorticating machine was as a result of the decorticating efficiency, throughput capacity and the percentage groundnut breakage. Therefore, the assessed results showed that the machine optimum efficiency was at $71.2 \%$ with a moisture content of $0 \%$ (d.b.) groundnut and 20 rpm machine shaft speed.

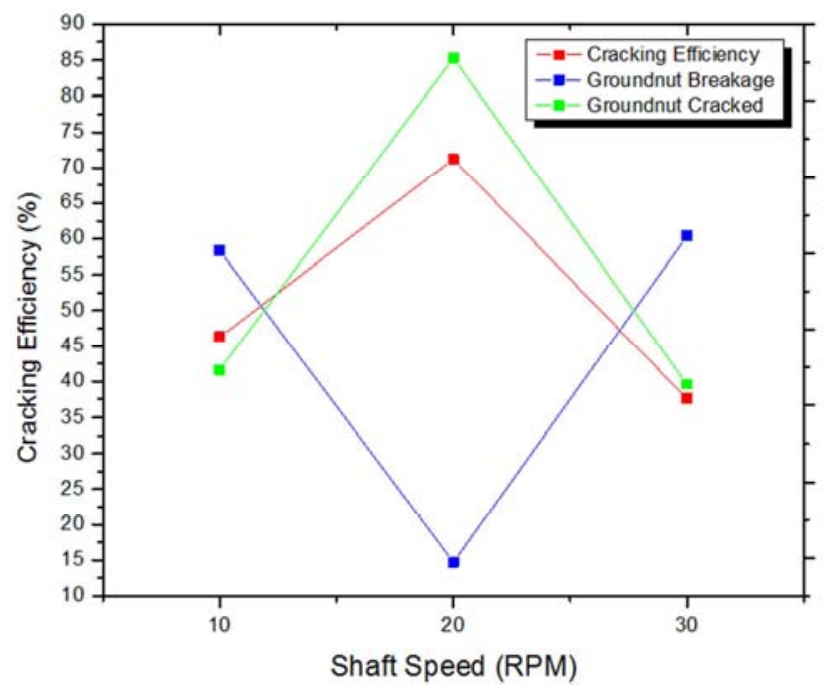

(a) Moisture content of $0 \%$ (d.b.) 


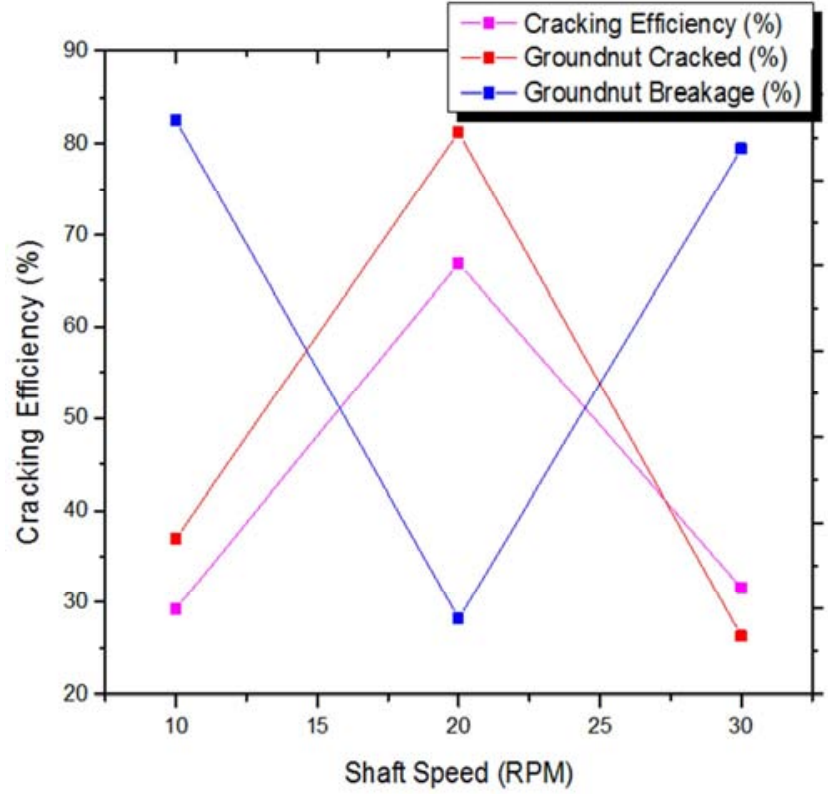

(b) Moisture content of $5.1 \%$ (d.b.)

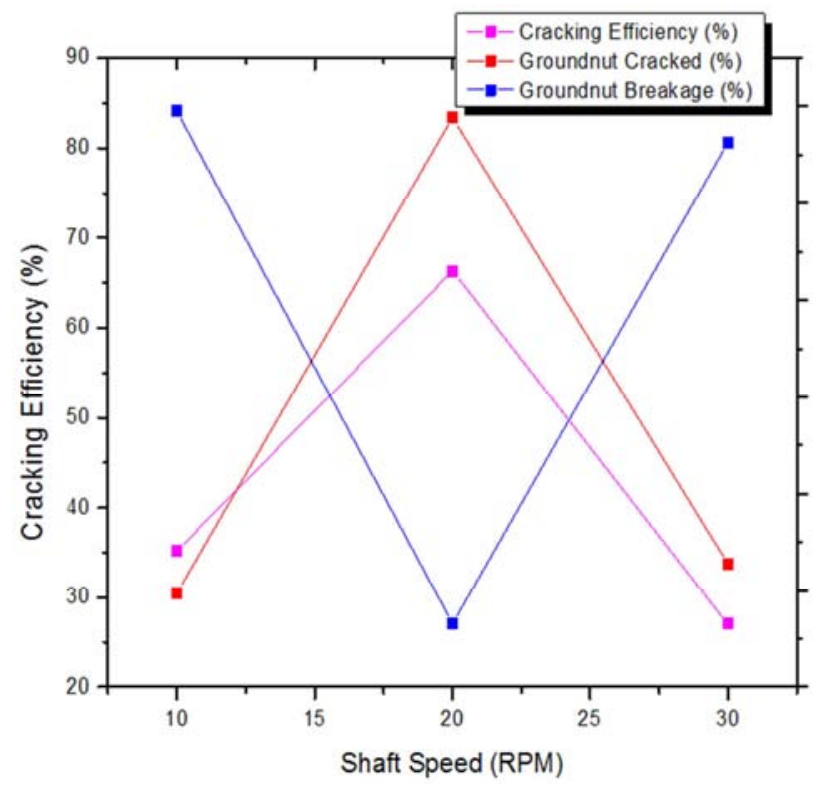

(c) Moisture content of $9.3 \%$ (d.b.)

Figure 3. Decorticator performance evaluation graph at different levels of moisture contents, cracking efficiency and shaft speed.

\section{Conclusion}

The following conclusions and recommendation are drawn from this work.

The machine can decorticate an average $350 \mathrm{~kg}$ of groundnut at a rate of $25 \mathrm{~kg}$. Due to this, it is recommended for small, medium and large scale industries in rural communities. The dual transmission system was selected for effective and efficient operation of the machine on the basis of twisting force and because of the rampant interruption of power supply in Ghana.

The blower was designed to separate the cracked from the un-cracked groundnut for easy processing.
The system is designed for the operator to either stand or sit to operate with ease, and comfort depending on the choice of the operator and it is therefore recommended for NonGovernmental Organizations (NGOs), municipal and metropolitan assembly and government can purchase this artefact for the rural farmer to boost the production, processing and large scale decorticating of groundnuts in Northern Ghana.

\section{Abbreviations}

The following abbreviations are used in this manuscript:

$\begin{array}{ll}\text { SSA } & \text { Sub-Sahara Africa } \\ \text { US } & \text { United States } \\ \text { LCC } & \text { Life Cycle Cost } \\ \text { MoFA } & \text { Ministry of Food and Agriculture }\end{array}$

\section{References}

[1] J. Beghin, N. Diop, H. Matthey, and M. Sewadeh, "The Impact of Groundnut Trade Liberalization: Implication for the Doha Round," in American Agricultural Economics Association Annual Meeting, July, 2003, pp. 27-30.

[2] P. Vijaya Kumar, Y. Ramakrishna, K. Krishna-Murty, and B. Ashok-Kumar, "AM Shekh Identifying the climatic constraints for optimum production of groundnut and delineating the areas with highest production potential on climatic basis," in Proc. of the symposium on Tropical crop Research and Development India International, Trissur, India, 1997.

[3] FAOSTAT (2011). FAOSTAT database. Retrieved from http://faostat.fao.org/. Accessed 20 July, 2015.

[4] Ministry of Food and Agriculture (2011). Statistics, Research and Information Directorate (SRID) Ghana.

[5] J. A. Akolgo, G. T. Kwadzo, and D. P. K. Amegashie, Comparison of the profitability of groundnut production in West Mamprusi andBunpkurugu-Yuyoo districts in Northern Ghana. Global Journal of Biology, Agriculture \& Health Sciences, Vol.3(2), 2014, pp. 144-151.

[6] Wumbei A. K., Koyiri, G., Ayariga, S. K, Anglarere, J. and Paul, F. (2000). Report on Women Income Generating Activities. A Study for IFAD/MoFA, Northern Region, Ghana.

[7] R. Awuah, O. Kwaku, S. Agyemang, C. Fialor, and C. Jolly, "Aflatoxigenic fungi and aflatoxin contamination of groundnut and groundnut-based products in Ghana: implications and concerns," in Proceedings of the National Workshop on Groundnut and Groundnut Aflatoxins Ghana, 2000.

[8] K. Sacilik, R. Öztürk, and R. Keskin, "Some physical properties of hemp seed," Biosystems Engineering, Vol. 86, 2003, pp. 191-198.

[9] O. C. Ademosun, Performance evaluation of cocao dehauling and winnowing machine, $A M A, 24(3), 1993,5-13$.

[10] J. A. Akpobi, and A. A. Oniah, Design and manufacturing of a palm fruit digester screw press, Nigeria Journal of Engineering management, 10(2), 2009, 10-19. 